\title{
Effects of weight loss on foot structure in obese adults: a pilot study
}

Jinsup Song ${ }^{1 *}$, Gary Foster ${ }^{2}$, Reagan Kane ${ }^{1}$, Dana N Tango', Stephanie Vander Veur ${ }^{2}$, Naomi Reyes², Caitlin LaGrotte ${ }^{2}$, James Furmato ${ }^{1}$, Eugene Komaroff ${ }^{2}$

From 3rd Congress of the International Foot and Ankle Biomechanics Community

Sydney, Australia. 11-13 April 2012

\section{Background}

Excessive body weight can have a profound influence on weight bearing structure and function, including pain, disability, and compromised quality of life. A prospective cohort study of 5,784 people over the age of 50 years, showed that obesity was a strong predictor of the onset of severe disabling knee pain.[1] Similarly, increased weight was found to have an association with chronic plantar heel pain syndrome.[2] No study to-date has conducted an objective prospective examination of the differences in foot structure and function during significant weight change.

Table 1 Summary of foot structure measures of the control and the treatment groups at baseline and 3-month

\begin{tabular}{lccccc}
\hline & \multicolumn{2}{c}{ Control } & \multicolumn{2}{c}{ Treatment } & \multicolumn{2}{c}{ p-value } \\
\cline { 2 - 5 } & Baseline & 3-month & Baseline & 3-month \\
\hline Body Mass Index ${ }^{\text {a }}$ & 35.8 & 35.1 & 36.1 & 34.0 & $<0.0001$ \\
Malleolar Valgus Index (\%) & 12.9 & 12.9 & 13.4 & 12.7 & 0.3103 \\
Standing arch height (cm) & 6.11 & 6.18 & 5.99 & 6.02 & 0.5593 \\
Arch drop (cm) & 0.44 & 0.40 & 0.43 & 0.47 & 0.0828 \\
\hline
\end{tabular}

${ }^{a}$ Control group lost an average of $1.9 \mathrm{~kg}(2.9 \%)$ of body weight while the treatment group lost $5.9 \mathrm{~kg}(6.2 \%)$ at 3-month visit.
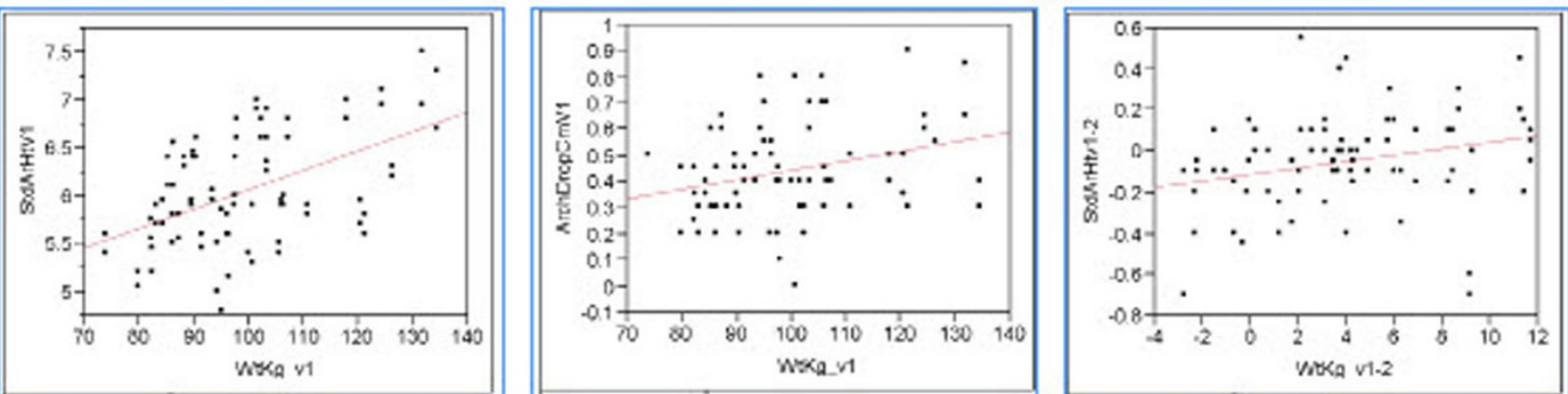

Figure 1 Linear correlation of (a) body weight and standing arch height at baseline [StdArchHt $=4.036+0.020 *$ Weight, $p<0.0001]$, (b) body weight and arch drop at baseline [Arch drop $=0.075+0.003 *$ weight, $P=0.006]$, and (c) change in weight and change in standing arch height $[\Delta \mathrm{StdArchHt}=-.0114+0.016 * \Delta$ Weight, $\mathrm{P}=0.013]$

\footnotetext{
* Correspondence: jsong@temple.edu

${ }^{1}$ Gait Study Center, Temple University, Philadelphia, PA, USA

Full list of author information is available at the end of the article
} 


\section{Materials and methods}

In this randomized controlled prospective pilot study, 41 obese subjects were randomly assigned to either the treatment or the control group. Subjects assigned to the treatment group received weekly education plus prepackaged portion-controlled meals while the control group received monthly education only. Foot structure measurements (malleolar valgus index and arch height) were assessed at baseline and 3-month. Repeated ANOVA (Matched Pairs by Group) analysis was performance using JMP 9.

\section{Results}

The mean age of study participants was 56.2 years old. While there was no difference in body mass index between the two groups at baseline, the treatment group lost significant weight at 3-month, see Table 1.

\section{Conclusions}

No significant changes were noted in measured structural foot parameters at 3-month follow up between the two groups as a function of observed weight loss. It is not clear if a larger weight reduction would have yielded significant changes. Several foot dimensions (including standing arch height and arch height drop from the sitting to standing conditions) were linearly correlated with body weight.

\section{Acknowledgements}

Nutrisystem, Inc. provided the pre-packaged portion-controlled meals for the study.

\section{Author details}

${ }^{1}$ Gait Study Center, Temple University, Philadelphia, PA, USA. ${ }^{2}$ Center for Obesity Research and Education, Temple University, Philadelphia, PA, USA.

Published: 10 April 2012

\section{References}

1. Jinks $C$, et al: Disabling knee pain - another consequence of obesity: Results from a prospective cohort study. BMC Public Health 2006, 6:258.

2. Irving DB: Obesity and pronated foot type may increase the risk of chronic plantar heel pain: a matched case-control study. BMC

Musculoskelet Disord 2007, 8:41.

doi:10.1186/1757-1146-5-S1-O48

Cite this article as: Song et al:: Effects of weight loss on foot structure in obese adults: a pilot study. Journal of Foot and Ankle Research 20125 (Suppl 1):O48.
Submit your next manuscript to BioMed Central and take full advantage of:

- Convenient online submission

- Thorough peer review

- No space constraints or color figure charges

- Immediate publication on acceptance

- Inclusion in PubMed, CAS, Scopus and Google Scholar

- Research which is freely available for redistribution

Submit your manuscript at www.biomedcentral.com/submit 